\title{
SPRY2 Gene
}

National Cancer Institute

\section{Source}

National Cancer Institute. SPRY2 Gene. NCI Thesaurus. Code C106027.

This gene is involved in the negative regulation of growth factor signaling. 